\title{
The Meanings of Sentence Insistence in Karo Language
}

\section{Efendi Barus}

Faculty of Literature, Universitas Islam Sumatera Utara, Medan, Indonesia

efendi_uisu@yahoo.com

\section{Abstract}

The aims of writing this research are to analyze about the use of particles in language and also the shift of words from one position to another one and they become what are called sentence insistence or sentence emphasis in Karo Language. The method of this research is by using descriptive research or library research. The analysis elaborates all types of insistence that can give effect to the meanings of the sentences which can be divided into 5 (five) types, such as: word stress, clauses in contradiction, the use of passive voice and the shift of words from one place to another one. The conclusion of this research shows the aspects of discussion such the types of insistence and how the meanings are found or described.
Keywords

insistence; particles; karo language

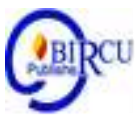

\section{Introduction}

Language is the human needs in their life due to in every activities, it must be there. No one can do anything without the use of language. Language has a very important influence in everyday life as a form of communication or social interaction (Sasmita, 2021). Language plays an important role in human life. Humans use language as a means to communicate. Language is related to the principle of politeness of language which is mentioned the maxims of wisdom, generosity, appreciation, simplicity, consensus and conclusions. So from the six maxims the adolescent must use a lot of maxims which expedite the conversation, cooperate with each other in speaking and give mutual appreciation in speaking and at least the simplicity maxim is needed (Darwis, 2018). Language is a medium of communication between humans. Language is needed by humans because human language can find their needs by communicating. As members of the community who are active in everyday life, people are very dependent on the use of language (Syahrin, 2018). That is why, it can be said that language is the device which can be used for communication among themselves. Every human beings when they communicate, they must use sentence. Sentence is a word or a group of words expressing a complete idea. The types of sentence can be classified into: imperative sentence, declarative sentence, interrogative sentence, and exclamatory sentence.

Translation is transferring the meaning from one language into another in the written form. Literary translation has a special position in identifying the culture of a country to other societies. The works of eminent writers and poets are available for other nations by the translation. Most of these figures have become famous through translation. According to comparison theory, the definition of metaphor is an implicit comparison without as or like between two compared items (Noie, 2018). What the researcher analyzed in this research is pertaining to the meaning of sentence insistence or sentence emphasis in Karo language. Insistence or emphasis is a special importance, value, or prominence given to word, part of sentence or the whole sentence. On the other hand, it can be said as stress laid on a word or words to indicate special meaning or particular importance. The 
insistence meaning is the special or extra force that is given to a word or part of words when it is spoken (Webster's New Worlds, Student's Dictionary, 1996:285). For example in English:

1) I think we should put as much emphasis on preventing disease as we do on curing it.

2) Schools here put/place/lay great emphasis on written work and grammar.

Instead of using insistence meaning, thematic meaning can also be applied or interpreted in this case. This insistence meaning can be identified from the sentence structure Using those types of sentences, besides mastering the norms of language, the language meaning must be obvious, empirical and do not give ambiguous meanings. That is why, one of the reasons why the researcher chooses this topic to be analyzed is that the hearers and the speaker understand the meanings of language communicated in the society by using the insistence sentences, such as using intonation, particles, adverbs, the movements of linguistic units from one place to another position, et cetera.

The ability of using language is not determined only by grammatical competence but also the skill or competence of how to use language. In this context, this research is done that is as the guidance to the language user particularly in Karo language.

It is already known by the people particularly those who are living in North Sumatera, that Karo language is mostly spoken in Karo land such as in Kaban Jahe, Berastagi, Deliserdang, Langkat and spreading to several provinces in Indonesia.

Karo language is dominated by vocal sound so that it is easily pronounced, clearly heard and easy to understand. The expression in Karo language has its own utterance and dialect (Barus, Efendi, 2015 : 448). One of the aspects that must be known in Karo language is the meaning of insistence sentence or emphasis sentence.

When the idea is put to emphasize in any place other than stress position, one of two things can happen. First, the reader will realize that the stress position is occupied by something that clearly isn'tworthy of emphasis. The second possibility is even worse: The reader may find the stress position occupied by something that does appear capable of receiving emphasis, even though it is not intended to any stress.

\section{Review of Literatures}

There are various degrees of accentuation or emphasis or insistence in an utterance may be signaled by means of intonation. Intonation can change the meanings of sentence.

Intonation can be classified into four: Primary accent, b. Secondary accent, c. Secondary accent without prominence, and d. Unaccented syllable (Gimson, 1989: 270).

The way of using insistence in language can be proposed here such as the use of particle, the shift of adverb, intonational insistence, etc in Karo language. On the other hand, Michel Swan, 1987: 200 said, emphasis means making one part of a sentence more important than it would normally be.

The word emphasis etymologically borrowed from Latin, "use of language to imply more than is actually said, implication (Late Latin also "appearance," Medieval Latin "prominence of expression, stress"), borrowed from Greek 'emphasis'.

\section{Research Methods}

The subject of this analysis is concerned with the Sentence Insistance in Karo Language. Meanwhile, there are several methods of data collection used in this study such as observation, interview, questionnaire, document study and writer's judgment. But in this 
analysis, the writer used document study or library research. There are several books which are related to the topic of discussion. This method is called descriptive research or qualitative research.

\section{Results and Discussion}

Karo language is very unique because of its pronunciation and intonation that is slowly raised and lowered. Many non-native speaker people like to hear Karo language spoken by the native speaker. Anyhow, the meaning of spoken language as it is known in this research is concerned with the meanings of insistence sentences.

In insistence sentence, the meaning can be varied by using accentuation, emphasis or stressing on a particular element or part of the sentence, so that those elements or part of the sentence on which are given stressing indicating the need of extra-approach or attention to the hearer or the readers.

Herewith, the types of insistence sentences or the emphasis sentence as part of exclamatory sentence can be discussed by analyzing the meanings of them in the following:

\subsection{The Meanings of Intonation Insistence}

Insistence by using intonation can be done only in oral language that is by giving emphasis on a particular element of a word or a group of words which are used, such as:

1) Nande erdakan i dapur

mother cook in kichen

"The mother cooked in the kichen"

2) Barus ermotor ku tiga ndai

Mr.Barus drove (the motor cycle) to the market just now

"Mr.Barus drove the motor cycle to the market just now"

3) Polisi nangkap pinangko manuk

Police cought thief chiken

"The police cought the thief of chiken".

The meanings of the sentence number:

1 ) is that the intonation to the italic word nande "mother" is stressed means the person who cooked in the kitchen, not the others.

2 ) is that the intonation to the italic word ermotor "drove the motor cycle" is placed the stress marker means the action is to drive the motor cycle not the car or bus.

3 ) is that the intonation to the italic word pinangko manuk "the thief of chiken" is stressed means the police cought the thief of chiken not other person.

\subsection{The Insistence of Meaning Contradiction}

The Insistence of Meaning Contradiction can be done in oral language or non-oral language in the equal compound sentences but they are in contrast between the first clause and the second one. For example:

1) kena tawa-tawa tapi aku ngamburken iluh you (pl) loughed but I poured tear

"You loughed happily but I poured the tear"

2) Ia mesunah akapna ndatken jodoh, aku mesera kuakap ndatkensa. He easily for him got partner, I difficult for me to get it. "He easily got partner for him, but I felt difficult for me to get it." 
3) Anakndu meteh mehuli, anakku la meteh mehuli.

Child you knew good, child my not knew good

Your child knew good manner, my child did not know good manner"

The meanings of the example 4.2 (a), (b) and (c) indicate contradictory between the first Clause and the second clause: loughed $><$ pour tear, easily got partner $><$ difficult to get partner, and knew good manner $><$ did not know good manner.

\subsection{The Insistence in the Form of Passive Voice}

The insistence in the form of Passive Voice can be done by using the object as the primary one in the sentence. Object is there when the verb is transitive form and the object is placed as the subject in the sentence. For example:

1) Biang ipek-pek anak perana adah.

Dog bit boy that

"the dog was bitten by that boy"(passive sentence)

That boy bit the dog (active sentence)

2) Nakan ipangan anakta.

Rice eat child our (poss.adj)

"The rice was eaten by our child" (passive sentence)

Our child ate the rice (active sentence)

3) Aku ibenter guru arah pudi

I throw teacher from behind

"I was thrown by the teacher from behind" (passive sentence)

The teacher threw me from behind (active sentence)

The meanings of the passive voice insistence can be illustrated that is number 3 (a) the dog is placed as the subject as in active sentence should be "that boy bit the dog", in this case the object of transitive verb is the dog but because of it is considered important, so it is placed as the subject, and so forth number 3 (b) and (c).

\subsection{The Shift of Adverb}

The shift of adverb can be done in the sentence to emphasize how, when, or where something occurred or done. When the adverb is shifted from one place to another position, in initial or final position may not change the meaning, but it is only to put adverb as the primary one. In communication, it can influence the meaning for the sake of emphasis or insistence. For example:

a. Erpagi-pagi ndai aku medak jam 5.30 labo jam 8 .

In the morning, I got up at 5.30, not at 8 o'clock.

"In the morning, I got up at 5.30, not at 8.00 o'clock." The adverb "in the morning" can be shifted to final position of the sentence, becomes: I got up at 5.30 not at 8.00 o'clock in the morning. The meaning can be illustrated that this morning, he got up early, but yesterday or tomorrow he may be late. When the adverb of time is placed at the end of the sentence, the subject "I" is emphasized who got up at 5.30, tomorrow, it may be another person.

b. I Indonesia, Virus Corona entah Covid 19 mulai erkembang. In Indonesia, Virus Corona atau Covid 19 begins spread.

In Indonesia, the Virus Corona or Covid 19 begins to spread"

The adverb of place in the sentence can be shifted to the end of the sentence, becomes "The Virus Corona or Covid 19 begins to spread in Indonesia". 
The shift of adverb of place to the end of the sentence may have meaning that, spreading Virus is not only in Indonesia but also in other countries are the same case. If it is in front of the sentence, it may indeed mean only in Indonesia the Virus begins to spread.

\subsection{The Insistence of Using Particles}

A case in point is to be found in the realm of particles. Without going into finer distinctions, particles are (usually) monosyllabic and uninflectable forms (Verschueren,1999: 204) Concerning with the particle, it is commonly said as grammatical particle. Particle is a kind of word which is not categorized with the class of words and cannot be grammatical inflections. Particle cannot be defined as lexical unit or cannot be inflected. For example: si, i, kin, kap, labo, lah, me, entah et cetera.

a. Particle kap that is used in between subject and predicate in a verbal sentence or adjectival sentence. For example:

- Aku kap engkelengi kam "It is I who love you".

- Kam kap erjabu bulan sireh "It is you who will get married next month."

- Lanai kap terulihi "It cannot be returned".

b. Particle si that is used between subject and predicate. For example:

- Ia si mejilena "She is the one of being beautiful".

- Ia si terjilen "She is the most beautiful".

- Aku si ndahi kam marenda "I who visited you last time".

The meaning of the second sentence is more insistent than the first sentence. The meaning of particle $s i$ is indicating the person who is concerned with something to do or the state of thing or person.

\section{Conclusion}

1) On the basis of the research which is already elaborated above, it can be said that there are five types of sentence insistence, though not all types are discussed here. They are the Meanings of Intonational Insistence, the Insistence of Meaning Contradiction, the insistence in the Form of Passive Voice, the Shift of Adverb and the Insistence of Using Particles. Those particles can be exemplified here, such as: stressing on a particular words in the sentences, the meaning in contradiction between the first clause and the second one, the insistence in the Form of Passive Voice, the Shift of Adverb and the Insistence of Using Particles.

2) The meanings of each insistences are giving effect to the sentences as well as the shift from one position to another one. To understand the meanings of language, it depends on the competence of the speaker how to use them and also the hearer how to understand it.

\section{References}

Arduengo, M. (2010, January 4). Advanced Writing Strategy: Place Information So People Can Find and Remember It.

Barus, Efendi. (2018). Article: Semantic Meaning of Suffixes in Karo Language. Papua: Universitas Papua, Indonesia.

Barus, Efendi. (2015). The International Proceeding Book: Educational Creativity and Innovation in Perspectives of the Asean - China Relations. Medan: Unimed Press. 
Chaer, Abdul. (2009). (dalam Brown 1976), Psikolinguistik Kajian Teorik. Jakarta: Rineka Cipta

Chaer, Abdul. (2010). Kesantunan Berbahasa.Jakarta Rineka Cipta

Darwin, Primsa. (1985). Sejarah dan Budaya Karo. Bandung : Yrama

Darwis, M. (2018). Politeness Language Analysis in Teenagers Reviewed from Sociolinguistics. Budapest International Research and Critics in Linguistics and Education (BirLE) Journal Vol I (1): 15-22.

Franz, Magnis. (2001). Pragmatik Kesantunan Inperatif Bahasa Indonesia. Jakarta : Erlangga

Gimson, A. C. (1989). An Introduction to the Pronunciation of English. Oxford University Press: London.

Ginting. E. P. (1996). Adat Perjabun Ibas Masyarakat Karo; Kinata Berita Simeriah Ibas Perjabun Kalak Karo. KabanJahe: Abdi Karya

Kreidler, Charles W. (1998). Introducing English Semantics. London: Routledge.

Leech, Geoffrey. (1974). Semantics: The Study of Meaning. (Second Edition). New York:

Penguin Books Ltd.

Lexy. J. Moleong. (2011). Metodologi Penelitian Kualitatif. Bandung: Remaja Rosdakarya

Lyons, John. (1995). An Introduction to Linguistic Semantics. Cambridge: Cambridge University Press.

Noie, S. (2018). An Investigation of Mystic Term on "Conference of The Birds" of Attar on The Basis of Van Doorslaer's Map. Budapest International Research and Critics in Linguistics and Education (BirLE) Journal Vol I (1): 1-10.

Rahardi. (2005). Pragmatik: Kesantunan Imperatif Bahasa Indonesia. Jakarta: Erlangga

Saragih, Amrin. (2006). Bahasa Dalam Konteks Sosial.

Sasmita, V., Adisaputera, A., and Saragi, D. (2020). The Influence of Social Interaction and Children's Language Ability on Students' Language Politeness in Class IV UPTD SD Negeri 06 Sei Muka, Datuk Tanah Datar District, Batu Bara Regency. Budapest International Research and Critics in Linguistics and Education (BirLE) Journal Vol 4 (1): 533-542.

Sitepu, Sempa. (2001). Pilar Budaya Karo. Medan: Bali Scan: Percetakan.

Sugiyono. (2009). Metode Penelitian Kualitatif dan R \& D. Bandung: Alfabeta

Swan, Michael. Practical English Usage. Oxford: Oxford University Press.

Syahrin, A. (2018). Culture Repertoire in Expressive Written Language : Study of Hypothesis of Edward Sapir and Benyamin Lee Whorf. Budapest International Research and Critics in Linguistics and Education (BirLE) Journal Vol I, No (1): 2328.

Tarigan, Sarjani. (2009). Lentera Kehidupan Orang Karo Dalam Berbudaya. Medan: SI BNB-BABKI, BABKI

Tarigan, Sarjani. (2008). Dinamika Orang Karo, Budaya Dan Modernisme. Medan: SI BNB-BABKI, ERGAJI

Tarigan, Sarjani. (2011). Kepercayaan Orang Karo. Medan: SI BNB Press

Ulina, Sri beru Tarigan \& Efendi Barus. 2018. Bentuk Kesantunan Dalam Tindak Tutur Perkawinan Adat Karo. Kota Tangerang Banten: Mahara Publishing.

Yule, George. (2003). Pragmatics. New York: Oxford University Press.

http://journal.uny.ac.id/index.php/hsjpi

https $/ /$ www.unl.edu/gradstudies/connections/ending-your-sentence. 